\title{
Analysis of Multistory Building with and without Floating Column
}

\author{
Mr. Dhananjay Bhoge ${ }^{1}$, Ms. Srushti Marde ${ }^{2}$, Ms. Bhumika Meher ${ }^{3}$, Mr. Rohan Tare ${ }^{4}$ \\ Mrs. Swati Dhurve ${ }^{5}$ \\ ${ }^{1234}$ (B.E. Student, Department of Civil Engineering, University of Mumbai, Palghar) \\ ${ }^{5}$ (Assistant professor, St. John College of Engineering and Management, Palghar)
}

Received on: 12 April, 2021, Revised on: 15 May, 2021, Published on: 16 May, 2021

\begin{abstract}
In the modern era of construction multistorey building with floating column play a major role in urban India. Thus, floating columns are used mainly for satisfying the space requirement in the structure and to get the good architectural view of building. The purpose of this study is to framing of the building having floating columns. The residential building comprising of $G+6$ storey structure has been selected for carrying out the project work. The work was carried out by considering different cases of columns in different position and in different floors of the building. Comparison will be done on maximum relative displacement, maximum axial force, maximum shear force and maximum bending moment of normal structure with floating column structure. This book presents the analysis of normal RCC column structure and floating column structure by using Staad Pro V8i software.
\end{abstract}

Keywords-Floating Column, Normal Building, Staad Pro

\section{I- INTRODUCTION}

M any urban multi-storey buildings in India today have open first storey as an unavoidable feature. This is primarily being adopted to accommodate parking or reception lobbies in the first storey. The floating column is a vertical member which rest on a beam and doesn't have a foundation. The floating column act as a point load on the beam and this beam transfers the load to the columns below it. But such column cannot be implemented easily to construct practically since the true columns below the termination level are not constructed with care and hence finally cause to failure. The floating column is used for the purpose of architectural view and site situations. It can be analyzed by using STAAD Pro.

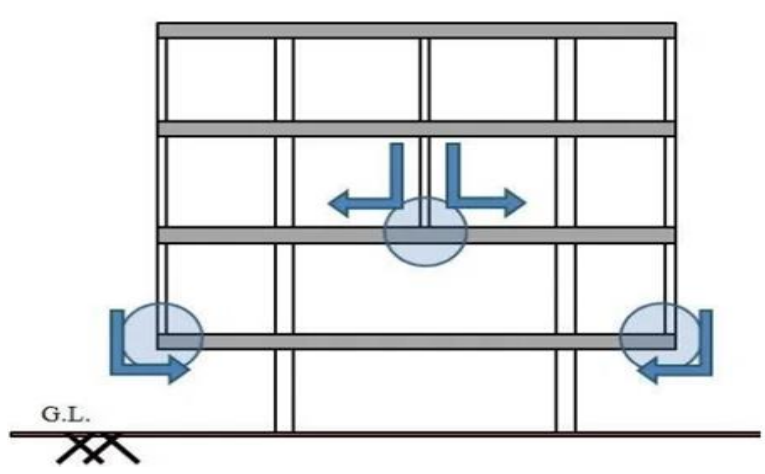

Fig. 1- Hanging or floating column

\section{II- OBJECTIVES}

- Basic study of floating column.

- To analysis RCC frame G+6 with floating column in different location.

- To compare the analysis of RCC frame G+6 with floating column and without floating column. 


\section{International Journal of Innovations in Engineering and Science, www.ijies.net}

\section{III- LITERATURE REVIEW}

Deekshita R, Dr. H. S. Sureshchandra June-2017: The main objective of this study is to analyze the G+5 storey building with floating column at different locations and also to check the storey displacement. Storey drift and storey shear for floating columns at various locations.

BadgireUdhavS. , Shaikh A.N. Maske Ravi G.-2015 : The main purpose of this study is to framing of the building having floating column $\mathrm{G}+10$ structures has been selected for carrying out the project work.

Sharma R.K.-June 2016: This paper deals with the variation in results in displacement of structure, base shear, load calculation of the building from manual calculation and Staad pro V8i. The study was carried out to find whether the floating column structures were safe or unsafe.

Ms.Priyanka D. Motghare-May 2016: This paper pertains of analytical studies carried out to evaluate the performance of RCC frame under different position of floating columns. The effect of position of floating column was also studied.

\section{IV- $\quad$ DETAILS OF PROJECT}

Table 1- Details of building

\begin{tabular}{|c|c|}
\hline Type of structure & $\begin{array}{l}\text { Multi-storied rigid jointed plane } \\
\text { frame }\end{array}$ \\
\hline Number of stories & $\mathrm{G}+6$ \\
\hline Floor height & $3 \mathrm{~m}$ \\
\hline Infill Wall & $\begin{array}{l}230 \mathrm{~mm} \text { thick brick masonry } \\
\text { wall }\end{array}$ \\
\hline Type of soil & Medium and hard \\
\hline Size of column & $350 \mathrm{~mm} \mathrm{X} 400 \mathrm{~mm}$ \\
\hline Size of beam & $300 \mathrm{~mm} \mathrm{X} 450 \mathrm{~mm}$ \\
\hline \multirow[t]{2}{*}{ Live load } & $\mathrm{ON}$ roof $=2 \mathrm{Km} / \mathrm{m} 2$ \\
\hline & On floor $=3 \mathrm{KN} / \mathrm{m} 2$ \\
\hline Material & $\begin{array}{l}\text { M20 grade concrete\& } 415 \\
\text { reinforcement }\end{array}$ \\
\hline \multirow[t]{2}{*}{ Unit weight } & Concrete $=25 \mathrm{Km} / \mathrm{m} 2$ \\
\hline & Masonry=20 Km/m2 \\
\hline $\begin{array}{l}\text { Total height of } \\
\text { building }\end{array}$ & $21 \mathrm{~m}$ \\
\hline
\end{tabular}

Table 2- Geometrical Dimensions of Building

\begin{tabular}{|c|c|c|c|}
\hline \multicolumn{4}{|c|}{ Member Dimension } \\
\hline \multicolumn{3}{|c|}{ Slab } & $150 \mathrm{~mm}$ \\
\hline \multirow[t]{3}{*}{ Beam } & \multicolumn{2}{|c|}{ Model 1} & $300 \mathrm{~mm} \mathrm{X} \mathrm{450mm}$ \\
\hline & \multicolumn{2}{|c|}{ Model 2} & $400 \mathrm{~mm}$ X 500mm \\
\hline & \multicolumn{2}{|c|}{ Model 3} & $650 \mathrm{~mm}$ X 500mm \\
\hline \multirow[t]{6}{*}{ column } & \multirow{2}{*}{$\begin{array}{c}\text { Model } \\
1\end{array}$} & External & $350 \mathrm{~mm}$ X 400mm \\
\hline & & Internal & $350 \mathrm{~mm}$ X 400mm \\
\hline & \multirow{2}{*}{$\begin{array}{c}\text { Model } \\
2\end{array}$} & External & $650 \mathrm{~mm}$ X 650mm \\
\hline & & Internal & $550 \mathrm{~mm}$ X 550mm \\
\hline & \multirow{2}{*}{$\begin{array}{c}\text { Model } \\
3 \\
\end{array}$} & External & $550 \mathrm{~mm} \mathrm{X} \mathrm{450mm}$ \\
\hline & & Internal & $550 \mathrm{~mm} \mathrm{X} \mathrm{450mm}$ \\
\hline \multicolumn{4}{|c|}{ Loads } \\
\hline \multicolumn{3}{|c|}{ Unit weight of concrete } & $25 \mathrm{KN} / \mathrm{m} 2$ \\
\hline & & Live Load & $3 \mathrm{KN} / \mathrm{m} 2$ \\
\hline & & Dead Load & $2 \mathrm{KN} / \mathrm{m} 2$ \\
\hline \multicolumn{4}{|c|}{ Grade of steel } \\
\hline & $\mathrm{am} \mathrm{\&} \mathrm{Co}$ & amns & $\mathrm{Fe} 415$ \\
\hline \multicolumn{4}{|c|}{ Support Condition } \\
\hline \multicolumn{3}{|c|}{ support } & Fixed \\
\hline
\end{tabular}

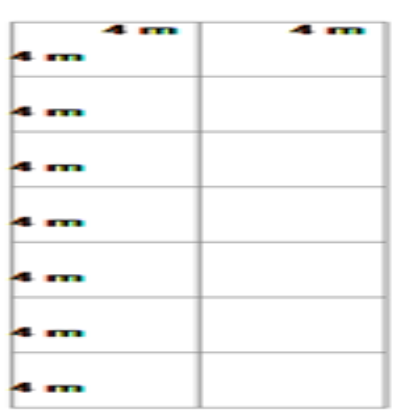

Fig. 2- Plan View

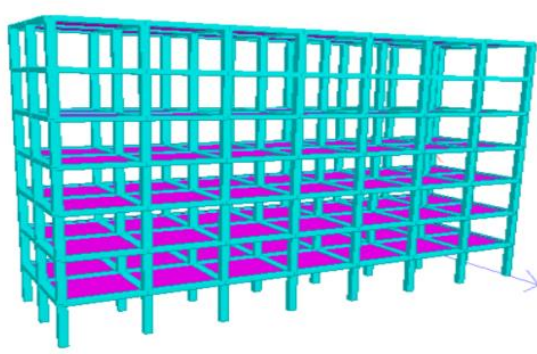

Fig. 3- Without Floating Column Building

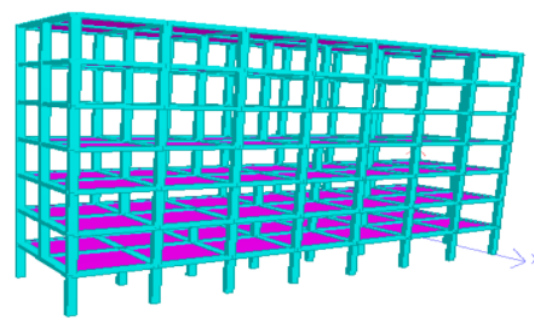

Fig. 4- With Floating Column Building 
International Journal of Innovations in Engineering and Science, www.ijies.net

\section{V- RESULTS AND DISCUSSION}

Maximum Relative Displacement

Table 3- Values of Maximum Relative Displacement

\begin{tabular}{|c|c|c|c|c|c|c|}
\hline \multirow[b]{3}{*}{ Storey No. } & \multicolumn{6}{|c|}{ Max. Relative Displacement (MM) } \\
\hline & \multicolumn{2}{|c|}{ Model No. 1} & \multicolumn{2}{|c|}{ Model No. 2} & \multicolumn{2}{|c|}{ Model No. 3} \\
\hline & $\begin{array}{l}\text { Without Floating } \\
\text { Column } \\
\text { (Case a) }\end{array}$ & $\begin{array}{l}\text { With Floating } \\
\text { Column } \\
\text { (Case b) }\end{array}$ & $\begin{array}{l}\text { Without } \\
\text { Floating } \\
\text { Column } \\
\text { (Case a) }\end{array}$ & $\begin{array}{l}\text { With Floating } \\
\text { Column } \\
\text { (Case b) }\end{array}$ & $\begin{array}{l}\text { Without } \\
\text { Floating } \\
\text { Column } \\
\text { (Case a) }\end{array}$ & $\begin{array}{l}\text { With Floating } \\
\text { Column } \\
\text { (Case b) }\end{array}$ \\
\hline GF & 0.1375 & 0.649 & 0.028 & 0.257 & 0.066 & 0.3475 \\
\hline 1 & 0.106 & 0.626 & 0.025 & 0.211 & 0.056 & 0.316 \\
\hline 2 & 0.1115 & 0.594 & 0.033 & 0.174 & 0.057 & 0.288 \\
\hline 3 & 0.1125 & 0.526 & 0.034 & 0.153 & 0.058 & 0.2695 \\
\hline 4 & 0.113 & 0.497 & 0.036 & 0.141 & 0.059 & 0.2525 \\
\hline 5 & 0.11 & 0.454 & 0.036 & 0.131 & 0.059 & 0.229 \\
\hline 6 & 0.109 & 0.436 & 0.0235 & 0.14 & 0.06 & 0.192 \\
\hline
\end{tabular}

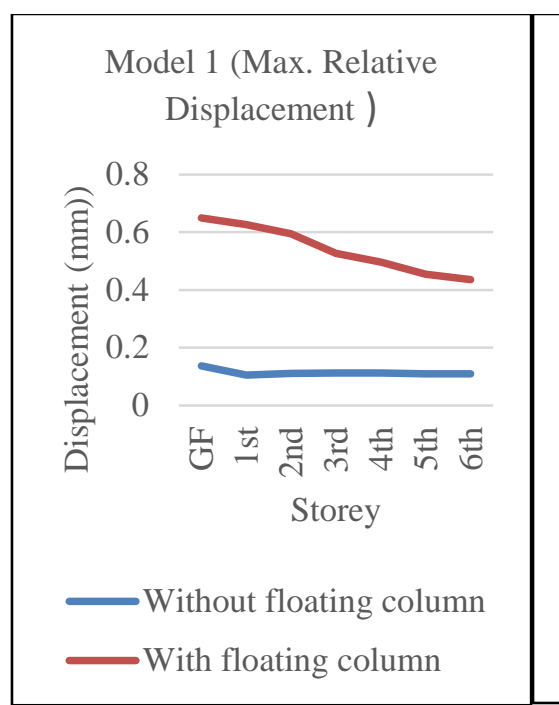

Fig.5- Model 1

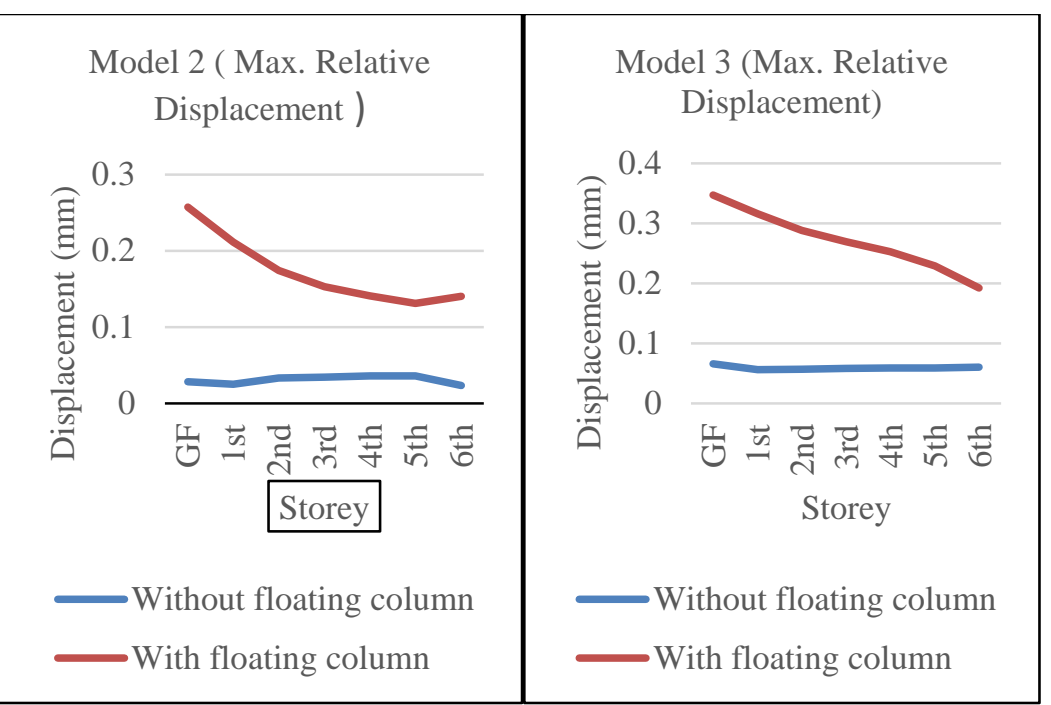

Fig.6- Model 2

Fig.7- Model 3

From the above graph it is found that displacement in floating column is increases as compare to without floating column. Also, as the storey increases (for higher storey) the value of maximum relative displacement decreases. 
International Journal of Innovations in Engineering and Science, www.ijies.net

\section{Maximum Axial Force}

Table 4- Values of Maximum Axial Force

\begin{tabular}{|c|c|c|c|c|c|c|}
\hline \multirow[b]{3}{*}{$\begin{array}{c}\text { Storey } \\
\text { No. }\end{array}$} & \multicolumn{6}{|c|}{ Max. Axial Force (KN) } \\
\hline & \multicolumn{2}{|c|}{ Model No. 1} & \multicolumn{2}{|c|}{ Model No. 2} & \multicolumn{2}{|c|}{ Model No. 3} \\
\hline & $\begin{array}{l}\text { Without } \\
\text { Floating } \\
\text { Column } \\
\text { (Case a) }\end{array}$ & $\begin{array}{c}\text { With Floating } \\
\text { Column } \\
\text { (Case b) }\end{array}$ & $\begin{array}{l}\text { Without } \\
\text { Floating } \\
\text { Column } \\
\text { (Case a) }\end{array}$ & $\begin{array}{c}\text { With Floating } \\
\text { Column } \\
\text { (Case b) }\end{array}$ & $\begin{array}{l}\text { Without } \\
\text { Floating } \\
\text { Column } \\
\text { (Case a) }\end{array}$ & $\begin{array}{c}\text { With Floating } \\
\text { Column } \\
\text { (Case b) }\end{array}$ \\
\hline GF & 0.581 & -2.864 & 2.533 & -9.045 & 0.562 & -4.971 \\
\hline 1 & 0.19 & -6.813 & 0.396 & -18.042 & -0.007 & -11.256 \\
\hline 2 & -0.068 & -6.308 & -0.392 & -16.498 & -0.185 & -10.656 \\
\hline 3 & -0.063 & -6.149 & -0.313 & -15.151 & -0.139 & -10.034 \\
\hline 4 & 0.096 & -4.741 & -0.085 & -12.936 & 0.055 & -8.424 \\
\hline 5 & -0.697 & -9.598 & -1.364 & -17.71 & -1.71 & -16.418 \\
\hline 6 & 0.884 & 7.558 & 0.94 & 13.082 & 3.584 & 13.672 \\
\hline
\end{tabular}

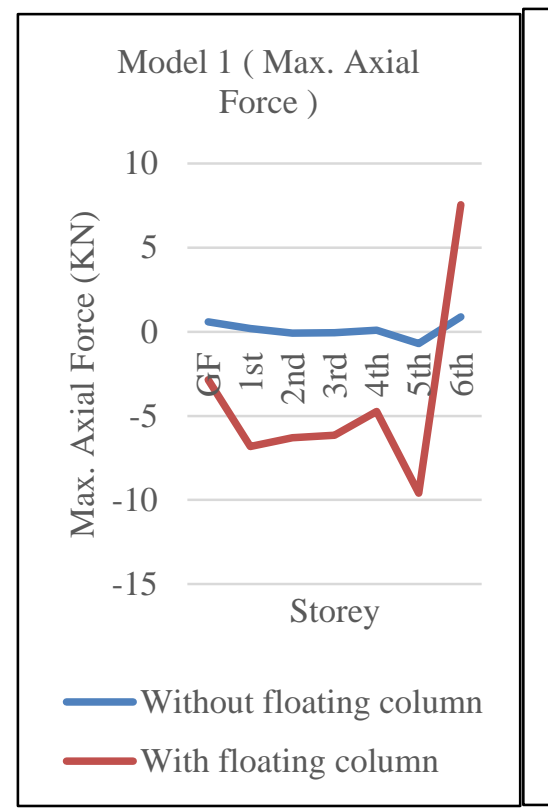

Fig.8- Model 1

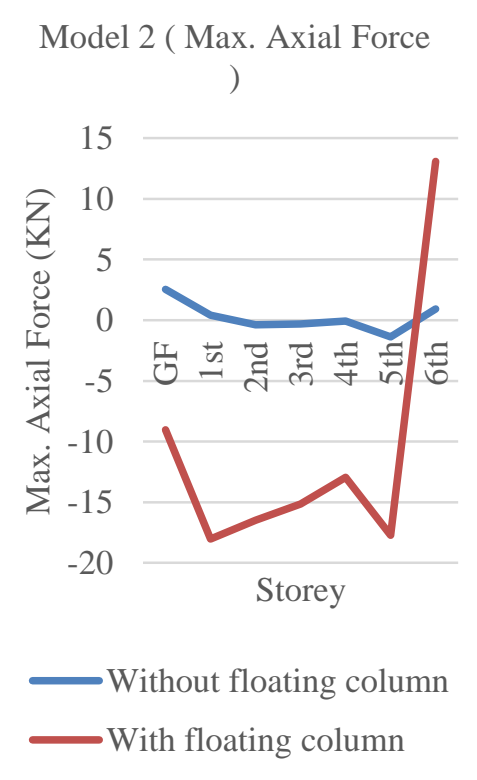

Fig.9- Model 2

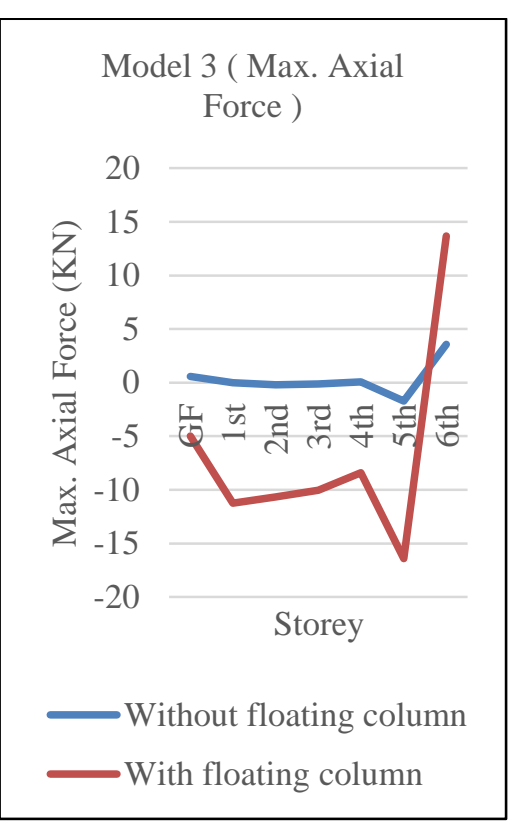

Fig.10- Model 3

From the above graph it is found that as the storey increases axial force also increases. In floating column building the value of axial force decreases as compare to normal without floating column building. 


\section{International Journal of Innovations in Engineering and Science, www.ijies.net}

\section{Maximum Shear Force}

Table 5- Values of Maximum Shear force

\begin{tabular}{|c|c|c|c|c|c|c|c|c|c|c|c|c|}
\hline \multirow{4}{*}{$\begin{array}{c}\text { Storey } \\
\text { Direction }\end{array}$} & \multicolumn{12}{|c|}{ Max. Shear Force $(\mathrm{KN})$} \\
\hline & \multicolumn{4}{|c|}{ Model 1} & \multicolumn{4}{|c|}{ Model 2} & \multicolumn{4}{|c|}{ Model 3} \\
\hline & \multicolumn{2}{|c|}{$\begin{array}{l}\text { Without } \\
\text { floating } \\
\text { column } \\
\text { (case a) }\end{array}$} & \multicolumn{2}{|c|}{$\begin{array}{l}\text { With floating } \\
\text { column } \\
\text { (case b) }\end{array}$} & \multicolumn{2}{|c|}{$\begin{array}{l}\text { Without floating } \\
\text { column } \\
\text { (case a) }\end{array}$} & \multicolumn{2}{|c|}{$\begin{array}{l}\text { With floating } \\
\text { column } \\
\text { (case b) }\end{array}$} & \multicolumn{2}{|c|}{$\begin{array}{l}\text { Without } \\
\text { floating column } \\
\text { (case a) }\end{array}$} & \multicolumn{2}{|c|}{$\begin{array}{l}\text { With floating } \\
\text { column } \\
\text { (case b) }\end{array}$} \\
\hline & $\mathrm{FY}$ & $\mathrm{FZ}$ & FY & $\mathrm{FZ}$ & FY & $\mathrm{FZ}$ & FY & $\mathrm{FZ}$ & FY & $\mathrm{FZ}$ & FY & $\mathrm{FZ}$ \\
\hline GF & 6.362 & 0.022 & 26.983 & 0.45 & 15.315 & 0.035 & 83.07 & 0.776 & 9.425 & 0.051 & 42.905 & 0.59 \\
\hline 1 & 6.542 & 0.011 & 25.158 & 0.088 & 15.315 & 0.012 & 69.448 & 0.358 & 9.515 & 0.034 & 39.351 & 0.238 \\
\hline 2 & 6.362 & 0.005 & 22.946 & 0.027 & 15.315 & 0.001 & 58.644 & 0.067 & 9.425 & 0.014 & 36.366 & 0.09 \\
\hline 3 & 6.362 & 0.001 & 21.765 & 0.028 & 15.315 & 0.001 & 52.594 & 0.086 & 9.425 & 0.003 & 34.135 & 0.029 \\
\hline 4 & 6.362 & 0 & 20.707 & 0.002 & 15.315 & 0.001 & 49.108 & 0.016 & 9.425 & 0.005 & 32.653 & 0.007 \\
\hline 5 & 6.362 & 0.011 & 20.05 & 0.05 & 15.315 & 0.01 & 48.164 & 0.253 & 9.425 & 0.033 & 30.658 & 0.091 \\
\hline 6 & 6.362 & 0.099 & 15.524 & 0.804 & 15.255 & 0.116 & 36.925 & 0.99 & 9.425 & 0.267 & 23.91 & 1.275 \\
\hline
\end{tabular}

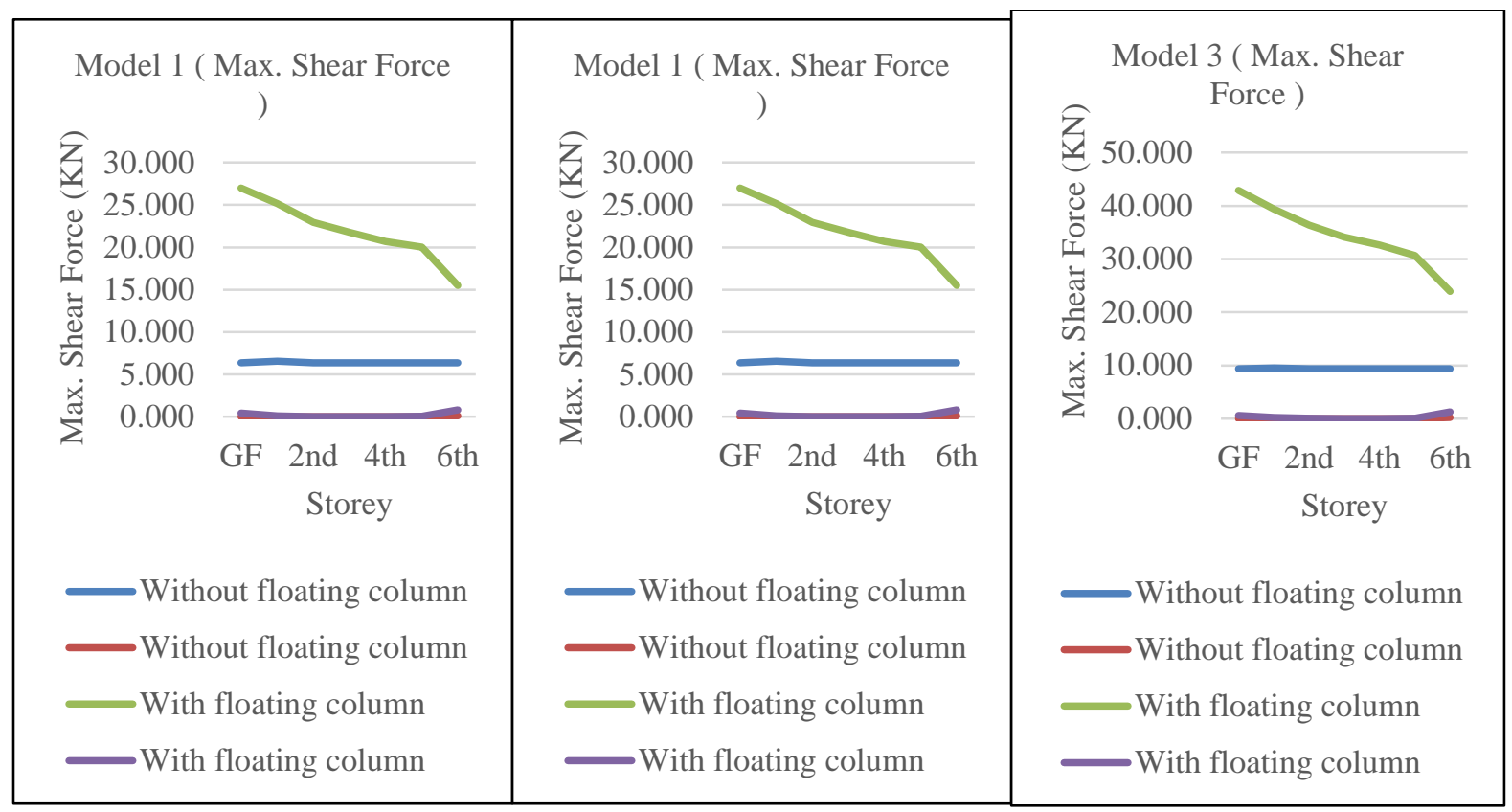

Fig.11- Model 1

Fig.12- Model 2

Fig.13- Model 3

The above Shear force graph, the $\mathrm{x}$ - axis showing the building storey \& Y-axis showing the Shear force value in KN. also graph shows the Shear force between without \& with floating column due to dead \& live load. By this load building gives the above value in Shear force. If we increase the number of floors the value of shear force decreases. 


\section{International Journal of Innovations in Engineering and Science, www.ijies.net}

\section{Maximum Bending Moment}

Table 6- Values of Maximum Bending Moment

\begin{tabular}{|c|c|c|c|c|c|c|}
\hline \multirow{4}{*}{ Storey No. } & \multicolumn{9}{|c|}{ Max. Bending Moment (KN.M) } \\
\cline { 2 - 7 } & \multicolumn{2}{|c|}{ Model No. 1 } & \multicolumn{2}{c|}{ Model No. 2 } & \multicolumn{2}{c|}{ Model No. 3 } \\
\cline { 2 - 7 } & $\begin{array}{c}\text { Without } \\
\text { Floating } \\
\text { Column } \\
\text { (Case a) }\end{array}$ & $\begin{array}{c}\text { With Floating } \\
\text { Column } \\
\text { (Case b) }\end{array}$ & $\begin{array}{c}\text { Without } \\
\text { Floating } \\
\text { Column } \\
\text { (Case a) }\end{array}$ & $\begin{array}{c}\text { With Floating } \\
\text { Column } \\
\text { (Case b) }\end{array}$ & $\begin{array}{c}\text { Without } \\
\text { Floating } \\
\text { Column } \\
\text { (Case a) }\end{array}$ & $\begin{array}{c}\text { With Floating } \\
\text { Column } \\
\text { (Case b) }\end{array}$ \\
\hline GF & 12.45 & 43.609 & 35.598 & 127.643 & 13.528 & 72.124 \\
\hline 1 & 4.75 & 39.688 & 11.984 & 103.349 & 7.005 & 65.054 \\
\hline 2 & 4.335 & 35.472 & 12.691 & 84.384 & 8.297 & 59.179 \\
\hline 3 & 4.469 & 33.245 & 13.405 & 33.825 & 8.804 & 55.441 \\
\hline 4 & 4.553 & 31.177 & 14.131 & 67.575 & 9.71 & 51.875 \\
\hline 5 & 4.86 & 30.298 & 15.678 & 67.249 & 9.512 & 48.114 \\
\hline 6 & 5.3 & 20.123 & 13.96 & 40.986 & 7.358 & 38.819 \\
\hline
\end{tabular}

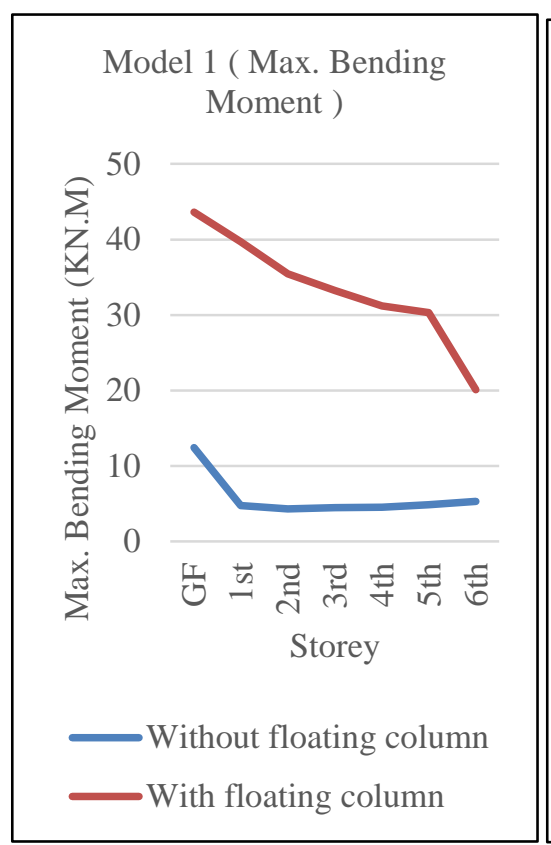

Fig.14- Model 1

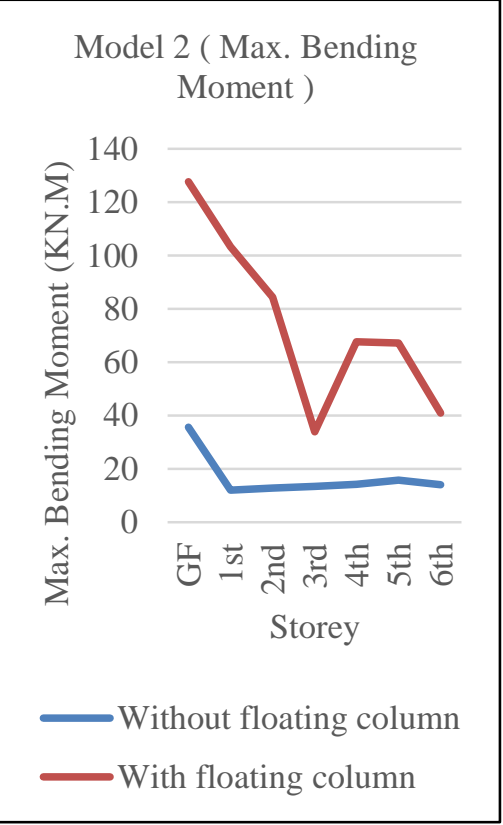

Fig.15- Model 2
Model 3 ( Max. Bending Moment )

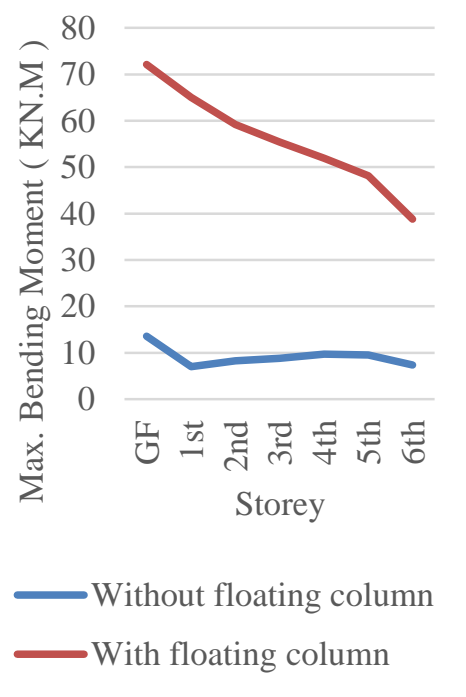

Fig.16- Model 3

The above Bending moment graph, the $\mathrm{x}$ - axis showing the building storey \& $\mathrm{Y}$-axis showing the Bending moment value in $\mathrm{KN}$-m. also graph shows the Bending moment between without \& with floating column due to dead \& live load. By this load building gives the above value in bending moment. If we increase the number of floors the value of shear force and bending moment also decreases. 


\section{International Journal of Innovations in Engineering and Science, www.ijies.net}

\section{VI- COMPARISON OF ANALYSIS RESULTS}

- First, we analyzed model-1 having column size 350x400 $\mathrm{mm}$ and Beam size 350x450 mm with floating column and without floating column. The floating column building having higher displacement as compare to normal structure.

- So, we analyzed the model-2 having external column size $650 \times 650 \mathrm{~mm}$ internal column size 550x550 $\mathrm{mm}$ and Beam size 400x500 mm with and without floating column then the floating column building displacement are lower than model-1 but greater than the normal structure.

- Then we analyzed model-3 having column size $550 \times 450 \mathrm{~mm}$ and Beam size is $650 \times 500 \mathrm{~mm}$ with and without floating column then the floating column structure having good result as compare to model-1 and model-2, so we select model-3.

- When we increase the beam size in model-3 then displacement is decreases but axial force, shear force and bending moments are increases.

\section{VII- CONCLUSION}

Following are the conclusions which are drawn on the basis of this test results,

$>$ As the numbers of storey increases the value of maximum relative displacement decreases but the value of maximum axial force, maximum shear force and maximum bending moments increases.

$>$ As the size of beam and size of columns increases the value of maximum relative displacement is decreases but the value of maximum axial force, maximum shear force and maximum bending moments is increases.

$>$ In frame structure with no floating columns the relative displacement is minimum with uniform distribution of stresses at all beams \& columns. As a result, it is most economical.

$>$ Use of floating columns results in the increase in the bending moment, shear force, \& steel requirement.

> Hence provision of floating column is advantageous in providing good floor space index but risky \& vulnerability of the building increases.

\section{REFERENCES}

[1] Aayush Gupta, Umesh Pendharkar (2020) multi-storey building with and without floating column (2020) International journal and Innovative Technology and Exploring Engineering. ISSN: 2278-3075, volume-9 Issue-4 feb-(2020).

[2] Abdul Azeed, Beebijahira H Tabgeri, Nidithkumar Shetty, SankarshamM. (2019) Analysis of Residential Building with floating column, Research journal of Engineering and Technology volume 6, Issue:05 May (2019).

[3] Deekshita R, Dr. H. S. Sureshchandra (2017) Analysis of multi-storeyBuilding with and without floating column International journal of Engineering Research and technology (IJERI) Vol. 6 Issue 6, ISSN : 22780181.

[4] Sasidhar T. P. Sai Avinash, n. Janardan (2017) Analysis of multi-storey Building with and without floating column International journal of Civil Engineering and technology volume-8, Issue-6, June (2017).

[5] BhukyaNagaraju, M. Suneetha. Design and analysis of G+12 with and without floating column (2017) using ETABS Anveshana's International Journal of Research Engineering and applied science volume-2, Issue-8, Aug (2017).

[6] Bhuvanesh Gawad, Swati Dhurve, "Strutural Assessment of old Building", Journal of Environmental Science, Computer Science and Engineering \& Technology 6(4): September 2017, Pages 466-478.

[7] Mamidala Ashwini \& Dr. Md. Subhan (2017) " Comparison of Buildings with And Without Floating Columns by Using Staad Pro" International Journal of Research, Volume 04 Issue 14, November (2017).

[8] BadgireUdhavS. Shaikh A.N. Maske Ravi G. (2015) Analysis of multi-storey Building with floating column International journal of Engineering Research volume no.4 Issue No.9 Pp: 475-478

[9] Garcia Reyes, Hajirasouliha Iman, PilakoutasKypros, (2010), "Seismic behaviour of deficient RC frames strengthened with CFRP composites". Engineering Structures 32 (2010) 3075-3085.

[10] Bhuvanesh Gawad, Swati Dhurve, "Health Safety and Risk Management in Residential Building", International Journal for Scientific Research \& Development, Volume 8, Issue 12, 2021, Pages 101-106.

[11] Agarwal Pankaj, Shrikhande Manish (2009), "Earthquake resistant design of structures", PHI learning private limited, New Delhi.

[12] Brodericka B.M., Elghazouli A.Y. and Goggins J, "Earthquake testing and response analysis of concentrically-braced sub-frames", Journal of Constructional Steel”, Prentice Hall. Research, Volume 64, Issue 9, Page no: 997-1007, (2008).

[13] Fall H.G (2006), "Direct Stiffness Method for 2D Frames Theory of structure". 


\section{International Journal of Innovations in Engineering and Science, www.ijies.net}

[14] Awkar J. C. and Lui E.M, "Seismic analysis and response of multistore semi rigid frames", Journal of Engineering Structures, Volume 21, Issue 5, Page no:425-442,1997.

[15] Bhuvanesh Gawad, "Concrete Mix Proportioning: A Short Note", Journal of Environmental Science, Computer Science and Engineering \& Technology 5(3): June 2016, Pages 262-266.

[16] Ms. Waykule S.B et al. Comparative Study of floating column of multi storey building by using software Int. Journal of Engineering Research and Application www.ijera.com ISSN: 2248-9622, Vol. 7, Issue 1, (Part 3) January 2017, pp.31

[17] User Manual of STAAD-Pro Software Developed by BENTLEY Systems.

\section{Details of All Authors:}

\begin{tabular}{|c|c|}
\hline Photo & Details \\
\hline & $\begin{array}{l}\text { Mr. Dhananjay Suresh } \\
\text { Bhoge } \\
\text { (BE-Civil Engineering) } \\
\text { St. John College of } \\
\text { Engineering and } \\
\text { Management, Palghar. }\end{array}$ \\
\hline & $\begin{array}{l}\text { Ms. Bhumika } \\
\text { Moreshwar Meher } \\
\text { (BE-Civil Engineering) } \\
\text { St. John College of } \\
\text { Engineering and } \\
\text { Management, Palghar. }\end{array}$ \\
\hline & $\begin{array}{l}\text { Ms. Srushti Sunil Marde } \\
\text { (BE-Civil Engineering) } \\
\text { St. John College of } \\
\text { Engineering and } \\
\text { Management, Palghar }\end{array}$ \\
\hline & $\begin{array}{l}\text { Mr. Rohan Rahul Tare } \\
\text { (BE-Civil Engineering) } \\
\text { St. John College of } \\
\text { Engineering and } \\
\text { Management, Palghar. }\end{array}$ \\
\hline & $\begin{array}{l}\text { Mrs. Swati Dhurve } \\
\text { (Assistant professor) } \\
\text { St. John College of } \\
\text { Engineering and } \\
\text { Management, Palghar }\end{array}$ \\
\hline
\end{tabular}

